Original Paper

\title{
Pemanfaatan Hutan Pantai Gading Sebagai Sumber Belajar untuk Meningkatkan Sikap Ilmiah Siswa Melalui Strategi Inkuiri
}

\author{
Haryani Sri Mardiyanti ${ }^{*}$ \\ ${ }^{1}$ Sekolah Menegah Atas Negeri 1 Mataram, Kota Mataram, Nusa Tenggara Barat, Indonesia
}

DOI: https://doi.org/10.29303/jcar.v3i2.892

*Corresponding Author: Haryani Sri Mardiyanti, Sekolah Menegah Atas Negeri 1 Mataram, Kota Mataram, Nusa Tenggara Barat, Indonesia.

Email:

Haryanivilla08@gmail.com

\begin{abstract}
Abstrak: Tujuan penelitian ini adalah untuk mengetahui apakah pemanfaatan lingkungan sebagai sumber belajar dengan menggunakan strategi inkuiri dapat meningkatkan sikap ilmiah siswa. Penelitian ini dilakukan pada siswa kelas X MIPA-2 SMA Negeri 1 Mataram yang berjumlah 39 siswa yang terdiri dari 25 siswa perempuan dan 14 siswa lakilaki. Penelitian ini mengambil lokasi di Hutan Pantai Gading Mataram yang beralamat di Jl. Lingkar Selatan Tanjung Karang, Kecamatan Sekarbela, Kota Mataram, Nusa Tenggara Barat. Instrumen penilaian sikap ilmiah digunakan untuk mengamati sikap ilmiah siswa dalam pembelajaran yang meliputi disiplin, kerjasama, kejujuran, percaya diri dan tanggung jawab. Data yang dikumpulkan dalam penelitian ini adalah data kualitatif berupa data sikap ilmiah siswa yang diperoleh melalui observasi langsung pada saat pembelajaran dan dianalisis dengan cara menghitung prosentase pencapaian sikap ilmiah dari setiap aspek sikap. Hasil penelitian menunjukkan bahwa strategi inkuiri dapat meningkatkan sikap ilmiah siswa. Terjadi peningkatan prosentase sikap ilmiah dari $83 \%$ menjadi $88 \%$ dan seluruh siswa telah mencapai predikat sikap baik (B) untuk seluruh aspek sikap yang meliputi disiplin, kerjasama, kejujuran, percaya diri dan tanggung jawab.
\end{abstract}

Kata kunci: sumber belajar; sikap ilmiah; strategi inkuiri

\section{Pendahuluan}

Pendidikan adalah usaha sadar dan terencana untuk mewujudkan suasana belajar dan proses pembelajaran agar peserta didik secara aktif mengembangkan potensi dirinya untuk memiliki kekuatan spiritual keagamaan, pengendalian diri, kepribadian, kecerdasan, akhlak mulia, serta keterampilan yang diperlukan dirinya, masyarakat, bangsa dan Negara (UU No. 20 Tahun 2003 tentang SISDIKNAS).

Pendidikan bertujuan untuk mengembangkan potensi peserta didik agar menjadi sumber daya manusia yang berkualitas. Sumber daya manusia berkualitas yang dimaksud adalah manusia yang beriman dan bertaqwa kepada Tuhan Yang Maha Esa, berakhlak mulia, sehat, berilmu, cakap, kreatif, mandiri, berdaya saing dan menjadi warga negara yang demokratis dan bertanggung jawab. Untuk mencapai tujuan tersebut, pemerintah telah berupaya melalui penetapan berbagai peraturan untuk menjamin agar setiap warga negara memperoleh pendidikan yang berkualitas.

Ilmu Pengetahuan Alam (IPA) berkaitan dengan cara mencari tahu (inquiry) tentang alam secara sistematis, sehingga IPA bukan hanya sebagai penguasaan kumpulan 
pengetahuan yang berupa fakta-fakta, konsepkonsep atau prinsip-prinsip saja, tetapi juga merupakan suatu proses penemuan.

Salah satu masalah dalam pendidikan IPA dewasa ini adalah kurangnya pemakaian sumber belajar untuk mendukung suatu kegiatan belajar mengajar. Biasanya sumber belajar selalu dikaitkan dengan alat dan bahan yang harus dibeli di tempat tertentu, sehingga alat dan bahan kadang-kadang menjadi sandungan bagi guru untuk menciptakan iklim belajar yang ideal.

Sebenarnya sumber belajar dapat juga diperoleh dari sekitar kita, misalnya dengan menugaskan siswa untuk membawa bendabenda tertentu ke sekolah. Di samping itu, lingkungan juga dapat digunakan dalam kegiatan belajar mengajar. Banyak benda, makhluk hidup atau fenomena-fenomena alam yang menarik dan dapat digunakan sebagai sumber belajar, hanya masalahnya guru belum terbiasa menggunakan lingkungan sebagai sumber belajar (Supinah, 1990 dalam Yeni, 2016).

Menurut Rustaman (1966) salah satu keuntungan menggunakan lingkungan sebagai sumber belajar adalah dapat mengembangkan motivasi dan prinsip "belajar bagaimana belajar (learning how to learn)" berdasar kepada metode ilmiah dan pengembangan keterampilan proses IPA sehingga tertanam sikap ilmiah.

Ditinjau dari karakteristik keilmuan biologi, proses pembelajaran biologi yang diharapkan menekankan pada keterampilan proses yang dilandasi sikap ilmiah. Namun, proses pembelajaran yang dilaksanakan masih menggunakan paradigma lama yaitu pembelajaran yang berpusat pada guru (teacher centered) dengan memilih model pembelajaran langsung. Dalam kegiatan pembelajaran guru lebih mengutamakan demonstrasi pengetahuan/ keterampilan dengan benar atau memberikan pengetahuan melalui ceramah yang disajikan dengan sangat sistematis. Rancangan pembelajaran seperti ini lebih bersifat pada menghafal atau rote learning dan menerima atau reception learning. Pikiran peserta didik dijejali dengan informasi-informasi sebatas yang dimiliki guru.

Sikap ilmiah adalah aspek tingkah laku yang tidak dapat diajarkan melalui pembelajaran tertentu, tetapi merupakan tingkah laku yang ditangkap melalui contohcontoh positif yang harus terus didukung, dipupuk, dan dikembangkan sehingga dimiliki siswa (Bundu, 2006). Pembelajaran IPA bukan hanya untuk menguasai sejumlah pengetahuan, tetapi juga harus menyediakan ruang yang cukup untuk tumbuh berkembangnya sikap ilmiah, berlatih melakukan proses pemecahan masalah, dan penerapannya dalam kehidupan nyata (Depdiknas, 2015).

Salah satu cara untuk mengembangkan sikap ilmiah adalah dengan memperlakukan siswa seperti ilmuwan muda sewaktu anak mengikuti kegiatan pembelajaran sains. Keterlibatan siswa secara aktif baik fisik maupun mental dalam kegiatan inkuiri membawa pengaruh terhadap pembentukan pola tindakan siswa yang selalu didasarkan pada hal-hal yang bersifat ilmiah.

Kenyataan yang ada di lapangan menunjukkan sikap ilmiah siswa dalam pembelajaran yang meliputi disiplin, kerjasama, kejujuran, percaya diri dan tanggung jawab masih kurang. Hal ini dikarenakan beberapa faktor, diantaranya adalah terbawa budaya lama yaitu proses pembelajaran yang masih berpusat pada guru sehingga aktivitas yang berkaitan dengan keterampilan belum berkembang secara optimal.

Dengan demikian, perlu adanya peran guru dalam menentukan strategi pembelajaran yang tepat, sehingga pembelajaran tidak hanya berpengaruh terhadap aspek pengetahuan, tetapi juga berpengaruh terhadap sikap dan keterampilan. Salah satu strategi pembelajaran yang dapat dipilih guru untuk meningkatkan sikap ilmiah siswa yaitu 
strategi inkuiri dengan memanfaatkan lingkungan sebagai sumber belajar.

Pembelajaran inkuiri adalah suatu rangkaian kegiatan belajar yang melibatkan secara maksimal seluruh kemampuan siswa untuk mencari dan menyelidiki secara sistematis, kritis, logis, analitis, sehingga siswa dapat merumuskan sendiri penemuannya dengan penuh percaya diri. Model pembelajaran ini dikembangkan oleh seorang tokoh yang bernama Suchman. Suchman meyakini bahwa anak-anak merupakan individu yang penuh rasa ingin tahu segala sesuatu (Sunarni, 2004).

Tujuan utama pembelajaran inkuiri adalah menolong siswa untuk dapat mengembangkan didisiplin intelektual dan keterampilan berpikir dengan memberikan pertanyaan-pertanyaan dan mendapatkan jawaban atas dasar rasa ingin tahu mereka. Selain itu inkuiri dapat mengembangkan nilai dan sikap yang sangat dibutuhkan agar siswa mampu berpikir ilmiah, seperti: (1) Keterampilan melakukan pengamatan, pengumpulan dan pengorganisasian data termasuk merumuskan dan menguji hipotesis serta menjelaskan fenomena; (2) Kemandirian belajar, keterampilan mengekspresikan secara verbal; (3) Kemampuan berpikir logis.

Pembelajaran inkuiri merupakan strategi pembelajaran yang memiliki banyak keunggulan diantaranya: (1) merupakan strategi pembelajaran yang menekankan kepada pengembangan aspek pengetahuan, sikap dan keterampilan secara seimbang, sehingga pembelajaran melalui strategi ini dianggap lebih bermakna; (2) dapat memberikan ruang kepada siswa untuk belajar sesuai dengan gaya belajar mereka; (3) merupakan pembelajaran yang dianggap sesuai dengan perkembangan psikologi belajar modern yang menganggap belajar adalah proses perubahan tingkah laku berkat adanya pengalaman; dan (4) menumbuhkan sikap objektif, jujur, hasrat ingin tahu, dan terbuka.

Berdasarkan uraian diatas, maka dilakukan penelitian dengan judul pemanfaatan hutan pantai gading sebagai sumber belajar untuk meningkatkan sikap ilmiah siswa melalui strategi inkuiri. Rumusan masalahnya adalah apakah pemanfaatan lingkungan sebagai sumber belajar dengan menggunkan strategi inkuiri dapat meningkatkan sikap ilmiah siswa?

Penelitian bertujuan untuk mengetahui apakah pemanfaatan lingkungan sebagai sumber belajar dengan menggunakan strategi inkuiri dapat meningkatkan sikap ilmiah siswa. Manfaat dari penelitian ini adalah memberikan sumbangan terhadap pembelajaran biologi, utamanya untuk meningkatkan sikap ilmiah siswa melalui penerapan strategi inkuiri, selain itu diharapkan penelitian ini dapat menjadi bahan acuan untuk mengembangkan strategi pembelajaran dan menjadi alternatif dalam mengatasi masalah pembelajaran khususnya pembelajaran biologi.

\section{Metode}

Subyek dalam penelitian ini adalah siswa kelas $X$ MIPA-2 tahun pelajaran 2018/2019. Adapun jumlah siswa sebagai subyek penelitian adalah 39 siswa, yang terdiri 25 siswa perempuan dan 14 siswa laki-laki. Penelitian ini dilaksanakan tanggal 16 Mei 2019.

Penelitian ini mengambil lokasi di Hutan Pantai Gading Mataram yang beralamat di Jl. Lingkar Selatan Tanjung Karang, Kecamatan Sekarbela, Kota Mataram, Nusa Tenggara Barat. Hutan Pantai gading sebagai sumber belajar merupakan laboratorium hidup yang sempurna untuk belajar ilmu lingkungan (biotik dan abiotik) karena kompleksitas ekosistem alami yang dimiliki.

Pembelajaran menggunakan strategi inkuiri untuk materi perubahan lingkungan dan target yang dicapai dalam penelitian ini adalah siswa dapat menganalisis data perubahan lingkungan, penyebab, dan dampaknya bagi kehidupan serta merumuskan gagasan pemecahan masalah 
perubahan lingkungan yang terjadi di lingkungan sekitar. Tahapan dalam penelitian digambarkan seperti Gambar 1:

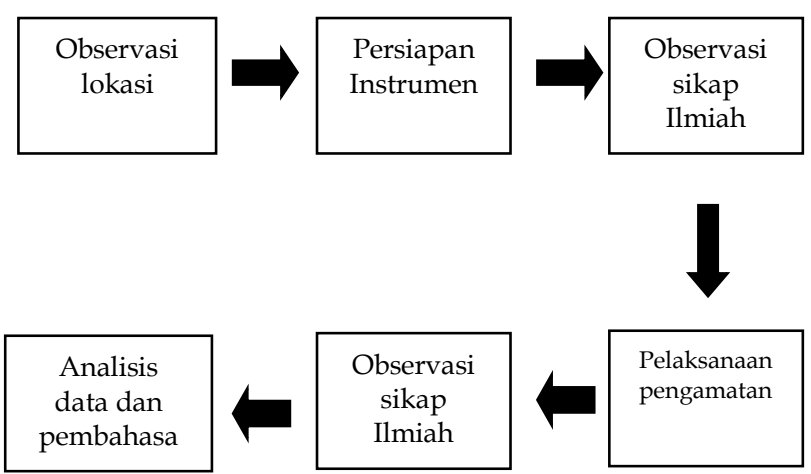

Gambar1. Tahapan Penelitian

Observasi lokasi untuk pengamatan siswa dilakukan 1 bulan sebelum kegiatan penelitian dilakukan. Observasi ini dilakukan untuk memastikan kondisi dari tempat yang digunakan sesuai dengan indikator yang telah ditetapkan. Disamping itu faktor keamanan siswa juga menjadi pertimbangan yang utama. Untuk memperoleh data yang akurat dalam penelitian diperlukan instrumen yang sesuai dengan tujuan yang ingin dicapai. Adapun instrumen yang digunakan dalam penelitian ini adalah instrumen penilaian sikap ilmiah.

Instrumen ini digunakan untuk mengamati sikap ilmiah siswa dalam pembelajaran yang meliputi disiplin, kerjasama, kejujuran, percaya diri dan tanggung jawab. Instrumen berupa skala penilaian yang dilengkapi rubrik penilaian. Data sikap ilmiah siswa diperoleh melalui observasi langsung pada saat pembelajaran dan dianalisis dengan cara menghitung prosentase pencapaian sikap ilmiah dari setiap aspek sikap dengan menggunakan rumus:

$$
\text { Nilai Akhir }=\frac{\text { Skor yang diperoleh }}{\text { Skor maksimum }} \times 100
$$

Predikat Sikap :

$\begin{array}{ll}\text { SB ( Sangat Baik }) & : 90-100 \\ \text { B }(\text { Baik }) & : 80-89 \\ \text { C }(\text { Cukup }) & : 70-79 \\ \text { K }(\text { Kurang }) & :<70\end{array}$

\section{Hasil dan Pembahasan}

Menurut Bundu (2006), pengukuran sikap ilmiah siswa sekolah dasar dapat didasarkan pada pengelompokkan sikap sebagai dimensi sikap, yang selanjutnya dikembangkan indikator-indikator sikap untuk setiap dimensi sehingga memudahkan dalam menyusun butir instrument sikap ilmiah. Sikap ilmiah diukur dengan menggunakan bentuk penilaian non tes.

Indikator keberhasilan penelitian ini dapat dilihat dari adanya peningkatan sikap ilmiah siswa pada akhir penelitian yang terlihat dari hasil penilaian sikap melalui observasi, yaitu jika seluruh siswa telah mencapai predikat sikap baik (B) untuk seluruh aspek sikap yang meliputi disiplin, kerjasama, kejujuran, percaya diri dan tanggung jawab.

Peningkatan sikap ilmiah siswa dalam pembelajaran dapat dilihat dari histogram pada Gambar 2:

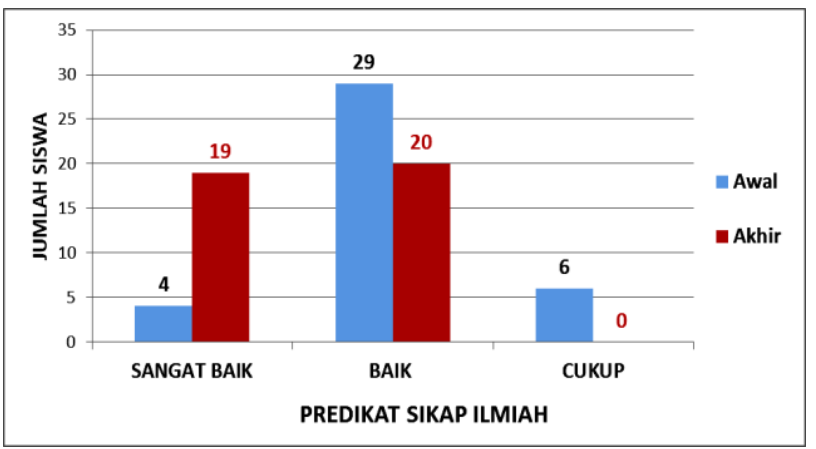

Gambar 2 2. Peningkatan predikat sikap ilmiah

Histogram pada Gambar 2 memberikan gambaran adanya peningkatan sikap ilmiah siswa dalam pembelajaran. Peningkatan predikat sikap ilmiah siswa dapat dilihat pada Tabel 1:

Tabel 1. Peningkatan predikat sikap ilmiah siswa

\begin{tabular}{llll}
\hline Predikat & Awal & Akhir & Peningkatan \\
\hline Sangat Baik & 4 & 19 & $38,5 \%$ \\
Baik & 29 & 20 & - \\
Cukup & 6 & 0 & - \\
\hline
\end{tabular}


Berdasarkan tabel 1.terlihat peningkatan yang signifikan sikap ilmiah pada predikat sangat baik yaitu sebesar 38,5\%, dari hasil observasi predikat sikap cukup tidak ditemukan lagi pada siswa. Hal ini membuktikan bahwa strategi inkuiri dengan menggunakan lingkungan sebagai sumber belajar dapat meningkatkan sikap ilmiah siswa. Peningkatan aspek sikap ilmiah siswa dapat dilihat dari histogram ada Gambar 3.

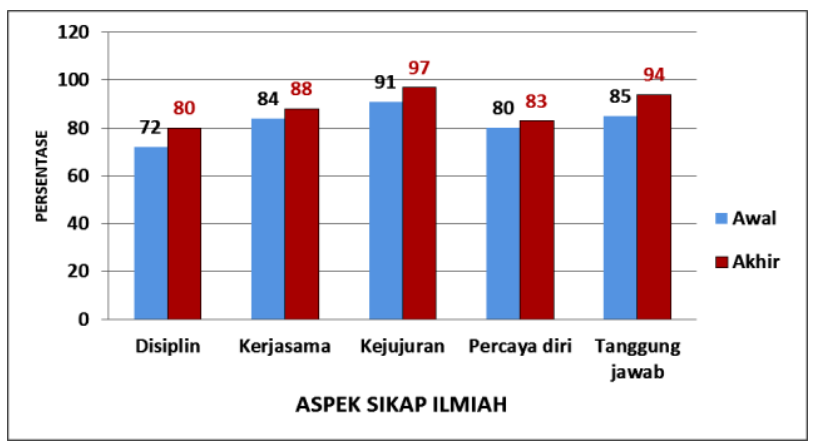

Gambar 3. Peningkatan Aspek Sikap Ilmiah

Peningkatan aspek sikap ilmiah siswa dapat dilihat pada Tabel 2:

Tabel 2. Peningkatan aspek sikap ilmiah siswa

\begin{tabular}{lccc}
\hline \multicolumn{1}{c}{ Aspek Sikap } & Awal & Akhir & ter \\
\hline Disiplin & 72 & 80 & \\
Kerjasama & 84 & 88 & \\
Kejujuran & 91 & 97 & ter \\
Percaya Diri & 80 & 83 & k \\
Tanggung & 85 & 94 & \\
Jawab & & & \\
\hline
\end{tabular}

Pada setiap aspek terjadi peningkatan sebagai berikut : sikap disiplin $(8 \%)$, sikap kerjasama $(4 \%)$, kejujuran $(6 \%)$, percaya diri (3\%) dan tanggung jawab (9\%) berarti Sikap ilmiah siswa mengalami peningkatan yang sangat signifikan dalam proses pembelajaran. Hal ini menunjukkan bahwa sikap ilmiah siswa mengalami peningkatan setelah siswa mengalami pembelajaran dengan menggunakan strategi inkuiri.

Proses pembelajaran dengan menggunakan strategi inkuiri ini siswa bekerja dalam kelompok untuk melakukan pengamatan pencemaran lingkungan yang terjadi di Hutan Pantai Gading Mataram. Untuk mengetahui pengaruh faktor abiotik terhadap faktor biotik (tumbuhan dan hewan) siswa melakukan pengukuran suhu, kelembaban, derajad keasaman tanah dan kecepatan angin. Dalam proses pengamatan itu diperlukan kerjasama yang baik dalam kelompok, kejujuran dalam memperoleh data, disiplin dengan waktu yang telah disediakan dan tanggung jawab terhadap alat-alat yang digunakan dalam pengamatan. Hal tersebut sangat mendorong terjadinya peningkatan sikap ilmiah secara signifikan.

Penelitian yang mendukung hasil ini adalah penelitian yang dilakukan oleh Maretasari et al., ( 2012) yang menunjukkan bahwa diperoleh peningkatan gain hasil belajar sebesar 0,53 dan peningkatan gain sikap ilmiah siswa sebesar 0,31. Sehingga dapat disimpulkan bahwa inkuiri terbimbing berbasis laboratorium mempunyai pengaruh yang signifikan terhadap hasil belajar dan sikap ilmiah siswa.

Penelitian senada yang dilakukan oleh Dewi (2013) pada siswa kelas IV SD Negeri di Kelurahan Kaliuntu menunjukkan: terdapRenimgededalik) sikap ilmiah dan hasil belajar IPA åttara siswa yang belajar dengan menggunakart model pembelajaran inkuiri terbimbing ${ }^{6}$ dan model pembelajaran konvensional $_{9}^{3}(\mathrm{~F}=29,110 ; \mathrm{p}<0,05)$, (2) terdapat perbedaan sikap ilmiah dalam pembelajaran IPA secara signifikan antara siswa yang belajar dengan menggunakan model pembelajaran inkuiri terbimbing dan model pembelajaran konvensional $(\mathrm{F}=22,649 ; \mathrm{p}<0,05)$, dan (3) terdapat perbedaan hasil belajar secara signifikan antara siswa yang belajar dengan menggunakan model pembelajaran inkuiri terbimbing dan model pembelajaran konvensional $(F=39,144 ; p<0,05)$.

Penerapan Strategi inkuiri dengan memanfaatkan lingkungan sebagai sumber belajar dapat meningkatkan sikap ilmiah siswa apabila dalam penerapannya melibatkan unsur-unsur pembelajaran yang maksimal. Di samping itu guru harus dapat 
mempertimbangkan keadaan internal peserta didik dalam setiap proses pembelajaran yang dilakukannya.

Hambatan yang dihadapi dalam pembelajaran menggunakan strategi inkuiri dengan memanfaatkan lingkungan sebagai sumber belajar diantaranya adalah jarak sumber belajar yang cukup jauh dari sekolah. Lokasi Hutan Pantai Gading berjarak $6 \mathrm{~km}$ dari sekolah. Di samping itu hambatan lain yang dijumpai adalah waktu kegiatan. Jam pelajaran yang tersedia dalam jadwal hanya 4 jam pelajaran dalam seminggu yang terbagi menjadi 2 kali pertemuan. Untuk mengatasi hambatan jarak yang cukup jauh ke tempat lokasi dilakukan kerjasama dengan orang tua siswa untuk membantu memfasilitasi kendaraan menuju ke lokasi pengamatan. Sedang untuk mengatasi hambatan waktu dilakukan negosiasi dengan guru mata pelajaran setelahnya dengan cara menukar jadwal pelajaran, sehingga kegiatan dapat dilakukan selama 4 jam pelajaran.

\section{Kesimpulan}

Berdasarkan hasil dan pembahasan dalam penelitian yang menggunakan strategi inkuiri serta memanfaatkan lingkungan sebagai sumber belajar dapat disimpulkan bahwa pemanfaatan lingkungan sebagai sumber belajar dengan menggunkan strategi inkuiri dapat meningkatkan sikap ilmiah siswa yang meliputi sikap disiplin, kerjasama, kejujuran, percaya diri dan tanggung jawab.

\section{Saran}

Dalam mengelola kegiatan pembelajaran biologi yang menggunakan strategi inkuiri dengan memanfaatkan lingkungan hutan pantai sebagai sumber belajar perlu mempertimbangkan beberapa hal: (1) Memerlukan pengelolaan jam belajar dan koordinasi dengan guru mata pelajaran lain, mengingat lokasi sumber belajar agak jauh dari sekolah; (2) Memerlukan alat transportasi untuk menuju ke sumber belajar.

\section{Daftar Pustaka}

Bundu, P. (2006). Penilaian Keterampilan Proses dan Sikap Ilmiah dalam Pembelajaran Sains. Erlangga. Jakarta

Direktorat Jenderal Pendidikan Dasar dan Menengah Kementerian Pendidikan dan Kebudayaan, 2017. Panduan Penilaian Untuk Sekolah Menengah Atas. Jakarta

Dewi, N.L. (2013). Pengaruh Model Pembelajaran Inkuiri Terbimbing Terhadap Sikap Ilmiah Dan Hasil Belajar IPA. e-Journal Program Pascasarjana Universitas Pendidikan Ganesha Jurusan Pendidikan Dasar. 3(1)

Maretasari, E., Subali, B., Hartono, H. (2012). Penerapan model pembelajaran inkuiri terbimbing Berbasis laboratorium untuk meningkatkan hasil Belajar dan sikap ilmiah siswa. Unnes Physics Education Journal, 1(2)

Sunarni, T. (2004). Model Pembelajaran Inovatif Berorientasi Konstruktivitis. Jakarta: Prestasi Pustaka

Yeni, H. (2016). Praktik Penggunaan lingkungan sebagai sumber belajar. PPPPTKIPA. Bandung 